\title{
Aging Interventions and Therapies
}


This page intentionally left blank 


\section{Aging Interventions and Therapies}

\section{Suresh I S Rattan University of Aarhus, Denmark}


Published by

World Scientific Publishing Co. Pte. Ltd.

5 Toh Tuck Link, Singapore 596224

USA office: 27 Warren Street, Suite 401-402, Hackensack, NJ 07601

UK office: 57 Shelton Street, Covent Garden, London WC2H 9HE

\section{British Library Cataloguing-in-Publication Data}

A catalogue record for this book is available from the British Library.

\section{AGING INTERVENTIONS AND THERAPIES}

Copyright $@ 2005$ by World Scientific Publishing Co. Pte. Ltd.

All rights reserved. This book, or parts thereof, may not be reproduced in any form or by any means, electronic or mechanical, including photocopying, recording or any information storage and retrieval system now known or to be invented, without written permission from the Publisher.

For photocopying of material in this volume, please pay a copying fee through the Copyright Clearance Center, Inc., 222 Rosewood Drive, Danvers, MA 01923, USA. In this case permission to photocopy is not required from the publisher.

ISBN 981-256-084-X

Typeset by Stallion Press

Email: enquiries@stallionpress.com

Printed in Singapore. 


\section{Contents}

Introduction vii

1. The Ethics of Aging Intervention and Life-Extension 1 Steven Horrobin

2. Prevention and Treatment of Skin Aging Jerry L. McCullough and Kristen M. Kelly

3. Industrial Approaches Towards Developing Effective Skin Care Products

Thomas Blatt, Horst Wenck and Franz Stäb

4. Strategies to Reduce Age-Related Skeletal Muscle Wasting Gordon S. Lynch, Thea Shavlakadze and Miranda D. Grounds

5. Antioxidants and Aging in Human Beings Éric Le Bourg

6. Hormone Therapy for Aging Mahendra K. Thakur

7. Pineal Peptides as Modulators of Aging Vladimir N. Anisimov and Vladimir Kh. Khavinson

8. Melatonin: Anti-Aging Perception and Current Perspectives Arvind L. Bhatia

9. Zinc and Other Micronutrients for Healthy Aging Eugenio Mocchegiani, Marco Malavolta and Efstathios S. Gonos 
vi $€$ Contents

10. Calorie Restriction as a Potent Anti-Aging Intervention:

Modulation of Oxidative Stress

Byung Pal ru

11. Nutritional Interventions in Aging and

Age-associated Disorders

Kenichi Kitani

12. Telomere- and Telomerase-based Therapies

Maria A. Cerone, Ryan Ward and Chantal Autexier

13. Clinical Perspective of the Present Status of Treatment for Major Age-related Diseases Ashit Syngle

14. Indian Ayurvedic Medicine in Aging Prevention and Treatment Bhupinder P. S. Vobra and Sanjeev K. Gupta

15. Alzheimer's Disease: Current and Future Treatments Umesh Kumar

16. Stem Cells, Regenerative Medicine and Aging Moustapha Kassem

17. Principles and Practice of Hormesis as an Aging Intervention 365 Suresh I. S. Rattan

18. Foreseeable and More Distant Rejuvenation Therapies Aubrey D.N.J. de Grey

19. Anti-aging Medicine and the Quest for Immortality

S. Jay Olshansky and Bruce A. Carnes

Index 


\section{Introduction}

During the last few years, tremendous progress has been made in our understanding of the biological basis of aging. Biogerontology is now a respectable and well-established field, and several universities, medical institutes and research centers throughout the world offer full-fledged courses on this topic. Most importantly, biogerontologists are now in a position to construct general principles of aging and explore various possibilities of intervention using rational approaches. While not giving serious consideration to the claims made by charlatans, it cannot be ignored that several researchers are making genuine attempts to test and develop various means of intervention for the prevention and treatment of agerelated diseases and for achieving healthy old age.

Aging Interventions and Therapies takes status of the molecular, cellular, hormonal, nutritional, medical and lifestyle strategies being tested and applied for the prevention, intervention and treatment of age-related diseases. The articles included in this book are specially written for this compendium by internationally leading researchers and practitioners at the universities, research institutes, hospitals, clinics and cosmetics and pharmaceutical industry. Furthermore, a philosopher and bioethicist addresses the ethical questions related to anti-aging and longevity promoting 
research, biodemographers discuss the practicality and impracticality of human lifespan extension, and a theoretical biologist-cum-biofuturologist reviews the futuristic technologies in development which will have serious bearings on aging intervention.

The target readership of Aging Interventions and Therapies is the undergraduate and graduate students in the universities, medical and nursing colleges, and post-graduates taking up studies and research projects on different aspects of aging and anti-aging. Practicing clinicians who would like to know about the latest developments in the field of aging intervention and therapy will find this book very useful. The topics covered in this book are also highly relevant for pharmaceutical, cosmeceutical and nutrition and healthcare industry for an easy access to accurate and reliable information in the field of aging research and intervention.

$$
\begin{array}{r}
\text { Suresh I.S. Rattan, Ph.D., D.Sc. } \\
\text { Editor } \\
\text { Danish Centre for Molecular Gerontoloy, } \\
\text { Department of Molecular Biology, } \\
\text { University of Aarhus, } \\
\text { Denmark. }
\end{array}
$$

